A NNALES

UNIVER S T ATIS M A R A E C URIE-SKŁODOW K A

LUBLIN - POLONIA

VOL. XXXIV, 1

SECTIO J

2021

Uniwersytet Marii Curie-Skłodowskiej w Lublinie. Wydział Pedagogiki i Psychologii

\author{
KAMILA MAGDALENA KOSIAK
}

ORCID: 0000-0002-6613-5181; kamila.kosiak@gmail.com

\title{
Diagnoza pedagogiczna zdolności i uzdolnień uczniów
}

Pedagogical Diagnosis of Students Abilities and Talents

Propozycja cytowania: Kosiak, K.M. (2021). Diagnoza pedagogiczna zdolności i uzdolnień uczniów. Annales Universitatis Mariae Curie-Skłodowska. Sectio J, Paedagogia-Psychologia, 34(1), 183-206. DOI: 10.17951/j.2021.34.1.183-206.

\begin{abstract}
ABSTRAKT
Kształcenie uczniów zdolnych jest swoistym wyzwaniem dla współczesnych szkół, wymaga bowiem odpowiednio prowadzonej polityki oświatowej oraz nakładów finansowych przeznaczonych na oświatę. Niezbędnym i najważniejszym czynnikiem są jednak odpowiednio przygotowani nauczyciele, którzy potrafią rozpoznać potrzeby edukacyjne i wychowawcze swoich uczniów. Niezwykle istotną kwestią jest trafna diagnoza zdolności i uzdolnień uczniów dokonywana przez nauczycieli, aby mogli je rozwijać i tworzyć optymalne warunki rozwoju podopiecznym. Obecnie najczęstszą formą stosowaną przez nauczycieli jest podział na uczniów zdolnych i niezdolnych za pomocą ocen szkolnych. Sposób ten wydaje się mało adekwatny, dlatego przeprowadzono badania przy użyciu autorskiego narzędzia - Skali do Badania Zdolności i Uzdolnień Stanisława Popka i Kamili M. Kosiak. Jest ono przeznaczone dla nauczycieli, a służy do rozpoznawania zdolności i uzdolnień w oparciu o podstawy teoretyczne oraz ujednolicone pojęcia zdolności i uzdolnień. Wyniki przeprowadzonych badań potwierdzają słuszność przyjętych rozwiązań.
\end{abstract}

Słowa kluczowe: nauczyciel; uczeń zdolny; diagnoza pedagogiczna

\section{WPROWADZENIE}

W efekcie wieloletnich badań nad osiągnięciami uczniów zdolnych oraz ich cechami osobowości powstało wiele opracowań dotyczących analizy tego pojęcia, a także podjęto próby scharakteryzowania poszczególnych grup uczniów (Bandura 1974; Gondzik, 1978; Borzym, 1979; Hornowski, 1985; Lewowicki, 1986; Popek, 1996, 2015; Sękowski, 2001; Giza, 2006; Limont, 2010; Magda-Adamowicz, 2011, 
2015; Dyrda, 2012; Gruszczyk-Kolczyńska, 2012). W związku z tym można by przypuszczać, że tak bogata literatura psychopedagogiczna pozwala nauczycielom na pełny rozwój uczniów zdolnych w szkole. Jednak mimo wielu dostępnych informacji często w środowisku edukacyjnym funkcjonują stereotypowe opisy uczniów zdolnych, niepotwierdzone przez opracowania naukowe (Limont, Cieślikowska, Dreszer, 2008). Zdolnymi najczęściej określa się tych uczniów, którzy wyróżniają się w pozytywny sposób na tle klasy. Powstało także fałszywe przekonanie o ich perfekcyjności, zgodnie z którym są to uczniowie bezproblemowi, odnoszą sukcesy i podwyższają prestiż szkoły. Zauważani przez nauczycieli są szczególnie ci, którzy są zmotywowani i chętni, wykazują entuzjazm w wypełnianiu codziennych obowiązków szkolnych oraz korzystają z szerokiego zakresu wiedzy i wiadomości pozaszkolnych, stanowiąc tym samym przykład dla pozostałych uczniów.

Należy zaznaczyć, że opis ten dotyczy tylko części osób zdolnych czy też uzdolnionych. Wbrew powszechnym wyobrażeniom uczniowie ci nie stanowią grupy homogenicznej, jednolitej. Zdolne mogą być przecież także osoby, które osiągają wyniki poniżej swoich możliwości. W Polsce problem ten został szczegółowo opisany jako „syndrom nieadekwatnych osiągnięć uczniów zdolnych”. Początkowo badacze różnie go definiowali, np. „uczniowie niewykorzystujący swoich możliwości”, a nawet „nieudacznicy” (Grzywak-Kaczyńska, 1935; Borzym, 1979; Tyszkowa, 1990; Butler-Por, 1993; Ekiert-Grabowska, 1994; Dyrda, 2007).

Badania prowadzone nad czynnikami, które powodują, że uczniowie posiadający potencjał nie wykorzystują go na miarę swoich możliwości, jak dotąd nie przyniosły jednoznacznych wniosków dotyczących tego zagadnienia (Renzulli, Reid, Gubbins, 1992). Jak wynika z opracowań, zjawisko to nie należy do rzadkich, szacuje się bowiem, że jest to nawet od 10\% do 50\% uczniów (Hoffman, Wasson, Christianson, 1985). Zaznacza się przy tym, że wyniki szkolne, które tak często decydują o sukcesie (m.in. według nauczycieli), mogą być zaniżone z powodu dysharmonii rozwojowej danego ucznia, ale może to również wynikać z braku zainteresowania programem szkolnym bądź posiadaniem przez ucznia pasji, której rozwijanie pochłania większość jego czasu, w efekcie czego brakuje go na przedmioty szkolne (Schwitzgebel, 1965), przy czym jest to wówczas świadomy wybór ucznia. Do braku trafnych ocen na miarę możliwości danego ucznia może przyczyniać się także tradycyjny, jednostronny system nauczania w szkole. Cechą charakterystyczną syndromu nieadekwatnych osiągnięć szkolnych jest jego złożoność. Na to zjawisko składają się zarówno problemy osobowościowe, rodzinne, jak i szkolne (Dyrda, 2012). Z tego powodu tak ważna jest dokładna znajomość uczniów i ich sytuacji pozaszkolnej.

Złożoność problematyki zdolności i uzdolnień skutkuje m.in. tym, że w literaturze przedmiotu nie ma jednoznacznej definicji pojęcia ucznia zdolnego. Wiele stanowisk teoretycznych powoduje trudności i zamęt w tym obszarze. Przywoływane jest rozumienie potoczne, stereotypowe (uczeń piątkowy, z sukcesami, 
poważny, zarozumiały, nietowarzyski, mający „swój świat”), ale też funkcjonują definicje naukowe, które nie są jednoznaczne i operują różnymi określeniami (zdolny, uzdolniony, utalentowany, twórczy, inteligentny, geniusz). Brak ujednolicenia wykorzystywanej terminologii oraz różne podejście autorów do tego zagadnienia w praktyce powoduje dalekosiężne skutki, przejawiające się m.in. nieodpowiednią opieką nad uczniami zdolnymi w szkole (nauczyciele nie potrafią wyselekcjonować właściwej definicji, najczęściej korzystają z kilku lub z wiedzy stereotypowej). Podczas prowadzenia badań naukowych również jest to problem, ponieważ studenci pedagogiki mają do czynienia z niepełną wiedzą w tym zakresie i nie zawsze aktualną (Szmidt, 2007; Magda-Adamowicz, 2011, 2015). Trafne diagnozowanie uczniów zdolnych, mimo że nie jest zadaniem łatwym, powinno być obligatoryjne, tym samym wzmocniono by znacznie kompetencje nauczycieli w tym obszarze (Magda-Adamowicz, 2011).

Ponadto istotna wydaje się być umiejętność odróżniania stylu uczenia się uczniów zdolnych i uzdolnionych od uczniów bystrych, którzy także osiągają wysokie wyniki w nauce, ale nie posiadają ponadprzeciętnych zdolności. Nie można zatem uczniów twórczych, zdolnych, uzdolnionych oraz zdolnych i bystrych zaklasyfikować do jednej grupy (mimo posiadania przez nich wysokich ocen szkolnych), gdyż nie przejawiają oni podobnych zachowań, a przede wszystkim nie mają identycznych potrzeb rozwojowych (Szabos, 1989; Popek, 1996; Drews, 2004; Limont, 2005; Dyrda, 2012).

Kolejnym istotnym zagadnieniem w procesie identyfikowania uczniów zdolnych i uzdolnionych jest świadomość tego, że oprócz zalet uczniowie ci mają również wady. Analiza badań nad funkcjonowaniem szkolnym uczniów zdolnych wykazała, że mogą to być też uczniowie problematyczni. Idealizowanie i definiowanie ucznia zdolnego jako najlepszego, wzorowego, o wysokiej średniej ocen, aktywnego, odpowiedzialnego ucznia sukcesu daleko odbiega od realiów współczesnej szkoły. Obszerne badania dotyczące wspomnianego „syndromu nieadekwatnych osiągnięć uczniów zdolnych" wskazują, że uczniowie z potencjałem, wykazujący cechy charakterystyczne odbiegające od idealnych (negatywne), nie są rozpoznawani i na ogół funkcjonują w systemie szkolnym poniżej swoich możliwości - uzyskują niskie wyniki w skali ocen, a przede wszystkim nie mają szansy na rozwój swojego potencjału.

Różnice w funkcjonowaniu szkolnym uczniów zdolnych zaprezentowała Bertie Kingore (2004), wyróżniając wśród uczniów trzy grupy: uczniów zdolnych, uczniów osiągających wysokie wyniki w nauce oraz uczniów twórczych. Podział ten został opracowany na podstawie wieloletnich obserwacji przeprowadzonych przez tę autorkę. Klasyfikacja ta może okazać się pomocna przy rozpoznawaniu uczniów zdolnych i uzdolnionych przez nauczycieli, ponieważ wskazuje na różne cechy, predyspozycje i funkcjonowanie uczniów zdolnych pod różnymi względami, nie tylko poznawczymi. Trzeba jednak zaznaczyć, że ta typologia nie jest konse- 
kwentna. Analizując wskazane charakterystyki, nauczyciel napotyka na określone sprzeczności. Wynika to z zatarcia różnicy między wyuczalnością w tradycyjnym znaczeniu a uzdolnieniami do rekonstrukcji wiedzy i wytwarzania nowych treści.

Przejście do edukacji współczesnej wiąże się ze zmianami w myśleniu ludzi: „Musimy być zdolni do porzucenia tkwiących w nas głęboko, zakorzenionych i sterujących naszym myśleniem i działaniem metafor: rzeźbiarza i gliny, banku i klienta, transmisji z góry do dołu, mistrza i naśladowcy z jednej strony, a z drugiej - ogrodnika i rośliny, pielęgniarki i samorozwoju do dojrzałości. Specjalista tak - ale krytyczny wobec własnej dyscypliny" (Kwieciński, 1980 s. 65). Przekaz ten, tak aktualny dla współczesnych nauczycieli, nakazuje porzucić dotychczasowy światopogląd, w którym nauczyciel-rzeźbiarz obrabia rzeźbę-ucznia. Musi się on stać przewodnikiem w odkrywaniu nowych rzeczy. Uczeń powinien funkcjonować przy pełnym zaufaniu osobie-nauczycielowi, który: prowadzi, ale nie steruje; pomaga, ale nie wykonuje czynności za niego; pokazuje, ale nie narzuca swojego światopoglądu.

Powyższe dylematy dotyczące definiowania w pedagogice uczniów zdolnych i uzdolnionych, uczniów osiągających wysokie wyniki w nauce oraz uczniów twórczych skłaniają do refleksji nad właściwą diagnozą. Różnice w ich funkcjonowaniu mają bowiem ogromne konsekwencje w pracy dydaktyczno-wychowawczej nauczycieli. Podkreślenie tych różnic nie jest możliwe bez właściwego rozpoznania ucznia oraz znajomości jego osobowości i sytuacji, w której się znajduje. Tylko wielopłaszczyznowe ocenianie i zróżnicowane metody nastawione na odkrywanie uczniów zdolnych dają szansę na powodzenie w stymulacji i wspieraniu rozwoju uczniów z potencjałem.

Analiza wielu badań naukowych (Bandura, 1974; Borzym, 1979; Lewowicki, 1986; Tyszkowa, 1990; Sękowski, 2001; Giza, 2006; Limont, 2010; Dyrda, 2012) pozwala na stwierdzenie, że większość z nich przeprowadzono na uczniach zdolnych. Syntetyczne spojrzenie na wielość definicji ucznia zdolnego skutkuje wieloma charakterystykami, występującymi zarówno w literaturze rodzimej, jak i obcojęzycznej. Ograniczeniem tych charakterystyk jest brak uporządkowania ich struktury bądź wąskie spostrzeganie zdolności w obrębie cech intelektualnych. Czynniki determinujące osiągnięcia szkolne są złożone. Stwierdzenie, że osiągnięcia szkolne są podyktowane poziomem ilorazu inteligencji, jest fałszywe (Tyszkowa, 1990).

Człowiek współczesny powinien spostrzegać otoczenie jako obszar niepewności poznawczej, taka sytuacja budzi bowiem pasję badawczą (Popek, 1996). Włączenie zdolności i uzdolnień w sferę osobowości, jako systemowo powiązanego składnika, prowadzi do holistycznego spojrzenia na psychikę ludzką. Systemowe ujmowanie zdolności uwzględnia przy tym opis funkcjonalny i strukturalny. Tak proponowane ujęcie jest możliwe tylko w świetle teorii interakcyjnej, ponieważ staje się wówczas systemem otwartym (Popek, 2015). Aby pojąć istotę zdolności, szukano jej wyznaczników czy atrybutów, które uwidaczniały się w czynnościach umysłowych i wykonawczych. 
Naukowe określenia uwzględniające sylwetkę ucznia zdolnego zwracają uwagę na różnorodność definicji i zróżnicowane charakterystyki. Analiza tych charakterystyk pozwala na podzielenie ich na kilka grup. Pierwsze z nich obejmują zdolności poznawcze i kierunkowe, powstałe najwcześniej, uwzględniające pomiary psychologiczne - przez ponad sto lat bazowały one na opisie zdolności do uczenia się. W drugiej grupie znajdują się charakterystyki związane z uzdolnieniami twórczymi. Do trzeciej grupy należy zaliczyć charakterystyki osobowościowe (Dyrda, 2012, s. 45). Z tego podziału wynikają implikacje dla całego systemu edukacyjnego. Otóż najłatwiej jest opisywać i badać inteligencję, o wiele trudniej zaś uzdolnienia twórcze (należą bowiem do kategorii bardziej ogólnych i złożonych), a najtrudniej jest opisać uzdolnienia specjalne, gdyż jest ich tyle, ile dziedzin działalności ludzkiej (Popek, 1996).

Analizując próby przybliżenia zdolności i uzdolnień, należy podkreślić, że uczniowie zdolni wyróżniają się z grona swoich rówieśników. Oprócz sprawności intelektualnej, którą można zauważyć najszybciej, posiadają często także bogatą wyobraźnię oraz potencjał do odkrywania nowych rzeczy. Niektórzy z nich cechują się też precyzją w działaniu w wąsko określonej dziedzinie (uzdolnienia specjalne) (Dobrołowicz, 1995). Nie można jednak upatrywać wszystkich przejawów zdolności i uzdolnień w jednym uczniu. Bywa i tak, że uczeń z wyjątkową wyobraźnią ma słabą pamięć lub inną funkcję poznawczą (Dobrołowicz, 1982; Popek, 1996; Magda-Adamowicz, 2011; Szmidt, 2007).

Najczęściej występującym w edukacji błędem dotyczącym charakterystyki uczniów zdolnych jest wyobrażenie, że uczniowie zdolni wykazują swoją ponadprzeciętność we wszystkich dziedzinach swojej aktywności. Tymczasem z wielu badań wynika, że dość często borykają się z asynchronią w swoim rozwoju. U tego samego dziecka może występować różny poziom rozwoju intelektualnego, społecznego, emocjonalnego czy fizycznego. Konsekwencją są trudności dydaktyczne i wychowawcze tych uczniów (Giza, 2006; Dyrda, 2012).

Postrzeganie uczniów zdolnych przez pryzmat ich sukcesów prowadzi nieuchronnie do idealizowania i wyboru uczniów bezproblemowych. Trzeba przy tym zdawać sobie sprawę z tego, że zadatki, jakie posiadają uczniowie zdolni, uzdolnieni czy twórczy, same w sobie nie gwarantują powodzenia. Równie ważna jest ich motywacja, zrozumienie oraz wsparcie w sferach, w których go potrzebują. Ponadto należy odróżnić styl uczenia się dzieci zdolnych od stylu uczenia się uczniów bystrych, którzy podobnie osiągają wysokie wyniki w nauce. Istnieją też uczniowie, którzy bardzo dobrych wyników w nauce nie zawdzięczają zdolnościom, lecz pracowitości, a także uczniowie twórczy, którzy nie mają na swoim koncie wysokich osiągnięć, ale posiadają nieograniczone możliwości wyobrażeniowe i odkrywcze.

Istotny jest zatem podział uczniów na wyżej wymienione grupy oraz spostrzeganie ich funkcjonowania poprzez pryzmat określonych cech charakterystycznych. Uczniowie zdolni nie stanowią jednorodnej grupy. Podobnie jak we wszystkich 
innych grupach społecznych istnieje w grupie tych uczniów duże zróżnicowanie, mamy tu do czynienia ze zmiennością zachowań czy zainteresowań (Limont, 2005; Magda-Adamowicz, 2011; Dyrda, 2012; Popek, 2015).

Podstawowe pytanie wspomagające rozwój jednostek działających niekonwencjonalnie dotyczy cech osobowości młodzieży twórczej. Badania empiryczne w tym zakresie zaczęto podejmować na szeroką skalę dopiero po 1950 r. Wcześniej głównym modelem wyjaśniającym działania sprawcze i innowacyjne był model intelektualny, w którym od czasów Francisa Galtona (1869) proces twórczy sprowadzany był do rozwiązywania problemów na drodze rozumowania (etapowe dochodzenie do problemu poprzez stawianie hipotez). Model ten zakładał pełną świadomość twórcy. Tak rozumiany proces twórczy polegał głównie na przekonstruowaniu nowych elementów (informacji) w elementy, które wcześniej były znane.

Współczesne koncepcje poznawcze twórczości obejmują dziedziny zarówno uczenia się, jak i zadań naukowych i technicznych. Niektórzy autorzy podkreślają, że są to dziedziny zbyt obszerne, aby móc dokonać generalizacji wszystkich odmian twórczości (Popek, 2015). Metody badań osobowości twórczych zmieniały się wraz z możliwościami badawczymi. Najwcześniej wykorzystywano metodę biograficzną. Badacze poddawali analizom następujące czynniki: pochodzenie, stosunki rodzinne, rozwój umysłowy do 15. roku życia, wychowawczy wpływ otoczenia (głównie na sferę intelektualną), sferę uczuciową, sferę woli, charakter, potomstwo, osiągnięcia twórcze. Obecnie dość pomocną metodą są badania cech kwestionariuszy i skal osobowości ludzi twórczych. Narzędzia te w istotny sposób przyczyniły się do skonstruowania zbioru arbitralnych cech, wspomagających m.in. rozpoznawanie osobowości twórczych. Obszernie i zarazem syntetycznie zostały one opisane przez Stanisława Popka (2015, s. 50). Nie jest jednak możliwe określenie jednorodnych cech i właściwości przypisanych do każdej jednostki twórczej. Oprócz cech wspólnych, inaczej ogólnych, każdy ma bowiem predyspozycje indywidualne, które pozostają ze sobą w różnych związkach.

Niezwykle ważna jest zatem trafność identyfikowania zdolności oraz uzdolnień dzieci i młodzieży. Profesjonalne podejście do diagnozy zdolności i uzdolnień uwzględnia kryterium pedagogiczne i psychologiczne. Pedagodzy jako nauczyciele mają bezpośredni, najczęściej długofalowy kontakt z uczniami, obserwują ich zachowanie na co dzień. Oceny stanowią wskaźnik osiągnięć szkolnych uczniów, ale nie są wskaźnikiem ich zdolności i uzdolnień. Analizując literaturę naukową i liczne badania, dostrzega się przede wszystkim potrzebę wielowymiarowego podejścia do uczniów. Ze względu na brak dostępnych narzędzi badawczych wielu nauczycieli ogranicza swoje rozpoznanie do oceny szkolnej, niektórzy z nich sięgają dodatkowo po diagnozy rówieśnicze czy od rodziców, które bardzo rzadko są potwierdzone badaniami w poradni psychologiczno-pedagogicznej.

Wiedza na temat uczniów zdolnych jest niezwykle ważna ze względu na możliwość wczesnego wspierania rozwoju zdolności i uzdolnień. Trafne rozpoznanie 
zapewnia systematyczne kontrolowanie rozwoju dzieci i młodzieży oraz umożliwia zastosowanie odpowiednich, adekwatnych oddziaływań psychologiczno-peadagogicznych. W przeciwnym wypadku następuje nieuniknione gubienie potencjału intelektualnego, a przede wszystkim uzdolnień twórczych (Popek, 2015). Ma to swoje przyczyny w ignorowaniu społecznych mechanizmów definiowania zdolności (Dyrda, 2012).

Do właściwej diagnozy konieczne jest również przyjęcie zbliżonej systematyki zdolności i uzdolnień oraz wprowadzenie jej do szkół na wszystkich poziomach kształcenia. Przyjęcie holistycznego modelu i konkretnych definicji oraz wieloaspektowe podejście do uczniów zdolnych i uzdolnionych stanowi pierwszy krok do właściwej, systematycznej diagnozy i rozwoju uczniów z różnymi predyspozycjami poznawczymi i społecznymi.

Podsumowując powyższe rozważania, należy zauważyć, że uczniowie zdolni wyróżniają się z grupy rówieśników m.in. takimi cechami, jak: poziom inteligencji, łatwość uczenia się, twórczość, zainteresowania pozaszkolne, wyobraźnia itd. Jest to heterogeniczny podział, obejmujący różne właściwości (m.in. osobowościowe, społeczne). Z pewnością nie można za pomocą jednej cechy (ilorazu inteligencji) wnioskować o zdolnościach czy uzdolnieniach uczniów.

\section{ZAŁOŻENIA METODOLOGICZNE BADAŃ}

Opierając się na założeniach interakcyjnych koncepcji zdolności, według których sprawność działania każdego człowieka jest wynikiem oddziaływania zróżnicowanych właściwości psychicznych oraz ich poziomu i wzajemnych relacji, zaprojektowano badania, których celem była diagnoza pedagogiczna osiągnięć szkolnych uczniów przy zastosowaniu własnego narzędzia badawczego - Skali do Badania Zdolności i Uzdolnień Uczniów Stanisława Popka i Kamili M. Kosiak (SdBZiUU). Za główne kryterium osiągnięć szkolnych uznano stopień opanowania wiedzy i umiejętności szkolnych określony przez program nauczania i wyrażony w ocenach szkolnych. Oceny szkolne stanowią w tym przypadku formalny wskaźnik osiągnięć szkolnych (powodzenie w nauce szkolnej).

Główny problem badawczy brzmi: Jaka jest diagnoza pedagogiczna zdolności i uzdolnień badanych uczniów?

Sformułowano następujące pytania szczegółowe:

1. Jaki jest poziom osiągnięć szkolnych badanych uczniów uzyskany na podstawie ich wyników?

2. Jakie są zdolności i uzdolnienia uczniów mierzone za pomocą Skali do Badania Zdolności i Uzdolnień Uczniów?

Aby nadać sens teoretyczny przyjętym konstruktom empirycznym, dokonano operacjonalizacji analizowanych zmiennych (tabela 1). 
Tabela 1. Operacjonalizacja analizowanych zmiennych

\begin{tabular}{|c|c|c|c|}
\hline & Nazwa zmiennej & Typ wskaźnika & Narzędzie badawcze \\
\cline { 2 - 4 } & $\begin{array}{c}\text { Poziom osiągnięć } \\
\text { szkolnych }\end{array}$ & $\begin{array}{c}\text { Wskaźnik empiryczny - } \\
\text { oceny szkolne }\end{array}$ & $\begin{array}{c}\text { Analiza dokumentacji } \\
\text { szkolnej }\end{array}$ \\
\cline { 2 - 4 } & & Wskaźniki empiryczne & \\
Zmienne & & składników zdolności & \\
pedagogiczne & i uzdolnień uczniów & \\
& Zdolności i uzdolnienia & Składniki: & Skala do Badania \\
& uczniów w ocenie & - poznawcze & $\begin{array}{c}\text { Zdolności i Uzdolnień } \\
\text { Uczniów Stanisława } \\
\end{array}$ \\
& nauczycieli & - społeczne & Popka i Kamili \\
& & - shakterologiczne & M. Kosiak \\
& & - emocjonalne & \\
& & - motywacyjn- & \\
& & wolicjonalne & \\
\hline
\end{tabular}

Źródło: opracowanie własne.

Zgodnie z założeniami teoretycznymi głównym wskaźnikiem osiągnięć szkolnych są udokumentowane oceny z poszczególnych przedmiotów nauczania, jakie uczniowie uzyskali na koniec semestru i roku szkolnego w I i II klasie liceum. Dokumentację wyników w nauce zebrano na podstawie arkuszy ocen, które zostały udostępnione za zgodą dyrektorów placówek.

Osiągnięcia szkolne zostały rozpatrzone w kategoriach ogólnych przedmiotów szkolnych. W celu określenia poziomu osiągnięć szkolnych w oparciu o podany wskaźnik obliczono średnie arytmetyczne ocen z nauki w I i II klasie liceum (zsumowano wszystkie oceny z końca semestru i roku szkolnego, następnie sumę ocen podzielono przez 4).

Podstawą wyodrębnienia grup zróżnicowanych pod względem wyników nauczania była uzyskana przez uczniów średnia ocen. Uczniów ze średnią poniżej 3,0 zaklasyfikowano do grupy o niskim poziomie osiągnięć szkolnych, natomiast uczniów ze średnią powyżej 4,0 - do grupy o wysokim poziomie osiągnięć szkolnych (por. Popek, 1987).

Następnie analizie poddano statystyczne średnie osiągnięć szkolnych, szeregując je od najwyższych do najniższych oraz przyporządkowując im wyniki osiągnięte w testach przez badanych uczniów. Zastosowana Skala do Badania Zdolności i Uzdolnień Uczniów należy do metod kwestionariuszowych. Powstała jako narzędzie eksperymentalne. Jej głównym zadaniem jest wspomaganie nauczycieli w dokonaniu trafnej diagnozy zdolności i uzdolnień uczniów, jest zatem przewidziana do stosowania przez nauczycieli.

Bazą do konstrukcji narzędzia była interakcyjna teoria osobowości. SdBZiUU powstała w oparciu o interakcyjny model zdolności autorstwa Popka. Skala została skonstruowana z uwzględnieniem modelu czynników warunkujących efektywne 
uczenie się twórcze i odtwórcze (rysunek 1). W celu skonstruowania narzędzia przebadano za pomocą kwestionariusza ankiety 120 nauczycieli (sędziów kompetentnych) pogrupowanych w obrębie przedmiotów humanistycznych i matematyczno-przyrodniczych. Przyjęty model zakłada, że na zdolności i uzdolnienia uczniów wpływają różne elementy, m.in. poznawcze, motywacyjno-wolicjonalne, charakterologiczne, emocjonalne oraz społeczne i środowiskowe.

Analogicznie w konstrukcji SdBZiUU wyodrębniono kilka podskal. Założono, że zdolności i uzdolnienia przejawiają się u młodzieży w kilku sferach funkcjonowania. Chodzi nie tylko o sferę poznawczą, lecz także o pozostałe, które są równie istotne. W związku z tym wszystkie nazwy poszczególnych funkcji (100) zostały pogrupowane, w efekcie czego powstało pięć głównych typów funkcji. Całe narzędzie składa się z pięciu podskal.

W zakresie sfery poznawczego funkcjonowania uczeń zdolny i uzdolniony charakteryzuje się wysokim poziomem inteligencji, łatwością koncentracji i bardzo dobrą pamięcią. Jest dociekliwy, zadaje mnóstwo pytań. Szybciej niż rówieśnicy wychwytuje to, co istotne, wyciąga trafne wnioski, potrafi zastosować wiadomości w praktyce. Uzdolnieni uczą się szybko i efektywnie. Często posiadają wiedzę pozaszkolną, co wynika z ich zainteresowań i dociekliwości. Mają bogatą wyobraźnię, są twórczy, mają bogaty zasób słownictwa. Opisy deklarowane przez nauczycieli stały się podstawą do stworzenia funkcji, a następnie pogrupowania ich w obrębie czynników (rysunek 1).

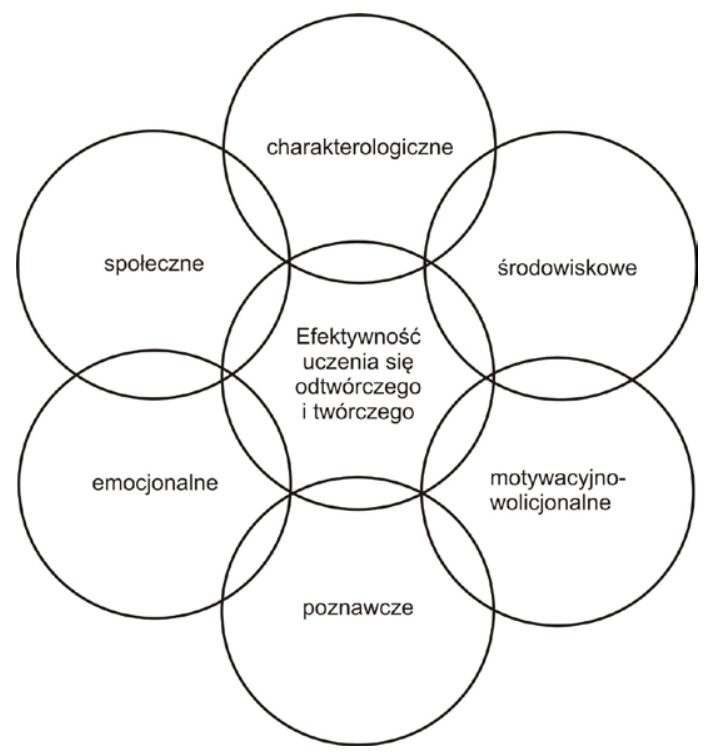

Rysunek 1. Model składników warunkujących efektywne uczenie się odtwórcze i twórcze Źródło: opracowanie S. Popka i K.M. Kosiak. 
Analizując sferę motywacyjną, można zauważyć, że uczeń jest ambitny. Jego dodatkowe cechy to aktywność, inicjatywa oraz skłonność do podejmowania ryzyka. Ponadto uzyskuje wyższe oceny, bierze udział w konkursach i podejmuje się wykonania dodatkowych prac domowych. Jest indywidualistą, woli pracować samodzielnie według własnego planu. Do swoistych cech uczniów zdolnych należy zaliczyć perfekcjonizm oraz zajmowanie się kilkoma rzeczami naraz.

Pod względem charakterologicznym uczniowie zdolni są systematyczni, pracowici, a przy tym rzetelni, wytrwali w dążeniu do celu. Mają wysokie aspiracje. Charakterystyczny dla nich jest silny indywidualizm. Uczniowie ci są zaradni i spontaniczni. W zakresie sfery emocjonalnej uczniowie zdolni są otwarci, śmiali i odważni. Często są bardziej zrównoważeni emocjonalnie niż ich rówieśnicy. Wyróżniają się także większą odpornością na niepowodzenia. Ponadto posiadają specyficzne cechy określające ich zachowanie w sferze społecznej. Młodzież zdolna odznacza się wysoką kulturą osobistą i nienagannym zachowaniem.

\section{BUDOWA SKALI}

Narzędzie rozpoczyna się instrukcją i metryczką. W dalszej części zamieszczono podstawowe informacje dotyczące ocenianych uczniów. Główną część stanowi skala, w której umieszczono nazwy 100 cech, procesów, funkcji oraz sposobu zachowania. Są to cechy i właściwości charakterystyczne zarówno dla uczniów mało zdolnych (niskie uzdolnienia), jak i uzdolnionych (wysokie uzdolnienia). Zadaniem nauczyciela jest postawienie krzyżyka w kolumnie dotyczącej nasilenia danej cechy u diagnozowanego ucznia.

Narzędzie skonstruowano w oparciu o teorię interakcyjną zdolności. Uwzględnia ono czynniki wewnętrzne (inteligencja, osobowość) i zewnętrzne (społeczne, środowiskowe) u uczniów, dzięki czemu ukazuje wielostronne podejście do procesu rozpoznawania zdolności i uzdolnień oraz pozwala zdiagnozować jego wpływ na efektywność uczenia się twórczego i odtwórczego wśród dzieci i młodzieży.

\section{ANALIZA WYNIKÓW BADAŃ}

Dokonując diagnozy pedagogicznej, w pierwszej kolejności przeanalizowano poziom osiągnięć szkolnych badanych uczniów, a następnie poziom zdolności i uzdolnień mierzony przy pomocy SdBZiUU.

W badanej próbie średni poziom osiągnięć szkolnych wyniósł $\mathrm{x}=3,56$ przy odnotowanej rozpiętości średnich ocen od $\mathrm{x}_{\min }=1,70$ do $\mathrm{x}_{\max }=5,43$ dla wszystkich przedmiotów szkolnych (tabela 2). 
Tabela 2. Statystyki opisowe osiągnięć szkolnych badanej próby uczniów

\begin{tabular}{|c|c|c|c|c|c|c|}
\hline \multicolumn{7}{|c|}{ Statystyki opisowe } \\
\hline & N & rozstęp & Min. & Max & średnia & $\begin{array}{c}\text { odchylenie } \\
\text { standardowe }\end{array}$ \\
\hline Średnia ocen & 221 & 3,73 & 1,70 & 5,43 & 3,5625 & 0,888 \\
\hline
\end{tabular}

Źródło: opracowanie własne.

Średnie ocen uczniów pogrupowano w następujące przedziały - oceny: 1) powyżej 4,50;2) od 4,50 do 4,00;3) od 3,99 do 3,50;4) od 3,49 do 3,00;5) od 2,99 do 2,50 ; 6) poniżej 2,50 (tabela 3 ).

Tabela 3. Średnie ocen uzyskane w ciągu czterech semestrów przez uczniów

\begin{tabular}{|c|c|c|}
\hline Średnie ocen & Częstość & Procent \\
\hline Powyżej 4,50 & 24 & 10,9 \\
\hline Od 4,00 do 4,50 & 98 & 44,3 \\
\hline Od 3,00 do 3,49 & 24 & 10,9 \\
\hline Od 2,50 do 2,99 & 49 & 22,2 \\
\hline Poniżej 2,50 & 26 & 11,8 \\
\hline Ogółem & 221 & 100,0 \\
\hline
\end{tabular}

Źródło: opracowanie własne.

Z przeprowadzonej analizy wynika, że ponad $40,0 \%$ badanych uczniów uzyskało średnie oceny w przedziale od 4,50 do 4,00 (44,3\%). Blisko co czwarta osoba uzyskała średnią ocenę w przedziale od 2,99 do 2,50 (22,2\%), a co dziesiąta - w przedziale od 3,49 do 3,00 (10,9\%) i powyżej 4,50 (10,9\%), co dziewiąta zaś poniżej $2,50(11,8 \%)$. Należy zatem stwierdzić, że niemal połowa badanych uczniów otrzymała wysokie oceny, a co dziewiąty wpisuje się w wyniki niskie.

Przy pomocy narzędzia eksperymentalnego zebrano i poddano analizie dane dotyczące zdolności i uzdolnień uczniów. Oceny tej dokonali nauczyciele. Skala obejmuje dwa poziomy: wysokie uzdolnienia oraz niskie uzdolnienia. Wszystkie zawarte w narzędziu funkcje zostały uszeregowane pod względem czynników zdolności i uzdolnień. Są to czynniki: charakterologiczne, środowiskowe, społeczne, motywacyjno-wolicjonalne oraz emocjonalne. Nauczyciele każdej funkcji nadawali rangę, gdzie 0 oznacza, że funkcja nie występuje, 1 -występuje na niskim poziomie, 2 - występuje na średnim poziomie, 3 - występuje na wysokim poziomie.

Podczas badań nauczyciele ze 100 funkcji zawartych w SdBZiUU wybrali 44 określenia, które ich zdaniem opisują badanych uczniów. Analizę zebranych danych empirycznych przeprowadzono na dwóch poziomach uzdolnień: wysokich i niskich. Wynikiem ogólnego poziomu zdolności i uzdolnień uczniów jest róż- 
nica między wysokimi i niskimi uzdolnieniami. Przewaga tych pierwszych może wskazywać uczniów o przeciętnych lub wysokich zdolnościach i uzdolnieniach.

O ile analiza wyników odbyła się w kierunku od zmiennych szczegółowych do zmiennych ogólnych, o tyle wyniki zostaną przedstawione według odwrotnego schematu: od zmiennych ogólnych do zmiennych szczegółowych. Ogólny poziom zdolności i uzdolnień obliczono metodą odchyleń standardowych. Różnica uzyskana między poziomem wysokich uzdolnień a poziomem niskich uzdolnień na podstawie wskazań nauczycieli określa zdolności i uzdolnienia uczniów. Średni poziom zdolności i uzdolnień wynosi 17,39, odchylenie standardowe 17,30, mediana 17,0 , minimum 28 , maksimum 54 . Niski poziom zdolności i uzdolnień nie występuje, ponieważ średnia minus odchylenie standardowe daje wynik bliski zeru. Można zatem założyć, że w tym przedziale znajdują się uczniowie, którzy nie wykazują żadnych zdolności i uzdolnień. Poziom przeciętny z kolei obejmuje osoby, które mają częściowe zdolności (np. tylko poznawcze lub emocjonalne albo motywacyjno-wolicjonalne), a w przedziale o wysokim poziomie zdolności i uzdolnień znajdują się uczniowie zdolni (tabela 4).

Tabela 4. Ogólny poziom zdolności i uzdolnień uczniów w ocenie badanych nauczycieli

\begin{tabular}{|c|c|c|}
\hline Wynik & Częstość & Procent \\
\hline Brak zdolności i uzdolnień & 35 & 15,8 \\
\hline Częściowe zdolności i uzdolnienia (do 35 pkt) & 146 & 61,1 \\
\hline Wysokie zdolności i uzdolnienia (powyżej 35 pkt) & 40 & 18,1 \\
\hline Ogółem & 221 & 100,0 \\
\hline
\end{tabular}

Źródło: opracowanie własne.

Natężenie wartości analizowanych zmiennych wskazuje, że blisko dwie trzecie badanych nauczycieli $(61,1 \%)$ stwierdziło, iż ich uczniowie wykazują częściowe zdolności i uzdolnienia. Należy zauważyć, że niemal co piąty respondent $(18,1 \%)$ zaakcentował, że jego uczniowie zaliczają się do grona osób wykazujących wysokie zdolności i uzdolnienia, predysponujące ich do działań twórczych, innowacyjnych. Natomiast co szósty nauczyciel $(15,8 \%)$ dostrzegł brak zdolności i uzdolnień u swoich podopiecznych.

Warto zauważyć, że co czwarty uczeń z rodziny inteligenckiej zdaniem nauczycieli jest ogólnie zdolny i uzdolniony $(22,8 \%)$. Z kolei uczniowie pochodzenia chłopskiego częściej niż pozostali badani mają częściowe zdolności i uzdolnienia (68,6\%). Ustalono też, że osoby mieszkające na wsi w ocenie pedagogów częściej niż pozostałe osoby mają częściowe zdolności i uzdolnienia (81,3\%). Środowisko rodzinne i lokalne $\mathrm{w}$ istotnym stopniu różnicuje zatem ogólny poziom zdolności i uzdolnień uczniów w ocenie nauczycieli $(\mathrm{p}<0,05)$. Co więcej, mężczyźni częściej niż kobiety diagnozowali u uczniów częściowe zdolności i uzdolnienia $(67,4 \%)$ 
( $<<0,041)$. Nauczyciele przedmiotów humanistycznych $(68,1 \%)$ i matematyczno -przyrodniczych podobnie ocenili ogólny poziom częściowych zdolności i uzdolnień podopiecznych $(63,1 \%)$. Stwierdzono także, że nauczyciele pracujący na wsi częściej niż pozostali pedagodzy diagnozowali u uczniów częściowe zdolności i uzdolnienia $(75,0 \%)(\mathrm{p}<0,007)$.

$\mathrm{Z}$ uwagi na to, że SdBZiUU jest narzędziem eksperymentalnym i nie zawiera norm dla badanych populacji, ogólny poziom wysokich zdolności i uzdolnień próby badawczej obliczono metodą odchyleń standardowych. Poziom przeciętny jest następujący: średnia $M=27,17$, plus/minus jedno odchylenie standardowe $\mathrm{SD}=15$, mediana 26 , minimum 0 , maksimum 68 . Poziom wysoki: średnia plus powyżej jedno i więcej odchyleń standardowych. Poziom niski: średnia minus poniżej jednego i więcej odchyleń standardowych. Niski poziom wysokich zdolności i uzdolnień wynosi poniżej $12 \mathrm{pkt}$, poziom średni - 12-42 pkt, a poziom wysoki - powyżej 42 pkt (tabela 5).

Tabela 5. Poziom wysokich zdolności i uzdolnień uczniów w ocenie badanych nauczycieli

\begin{tabular}{|c|c|c|}
\hline Wynik & Częstość & Procent \\
\hline Poziom niski (poniżej 12 pkt) & 35 & 15,8 \\
\hline Poziom przeciętny (12-42 pkt) & 146 & 66,1 \\
\hline Poziom wysoki (powyżej 42 pkt) & 40 & 18,1 \\
\hline Ogółem & 221 & 100,0 \\
\hline
\end{tabular}

Źródło: opracowanie własne.

Uzyskane dane pozwalają stwierdzić, że wśród nauczycieli dominuje przekonanie o przeciętnym poziomie wysokich zdolności i uzdolnień badanych uczniów (66,1\%). Częściej takiej diagnozy dokonywały kobiety niż mężczyźni pracujący jako nauczyciele $(\mathrm{p}<0,05)$. Poziom wysoki charakteryzuje co piątego respondenta w ocenie nauczycieli $(18,1 \%)$. Natomiast co szósty jedynie w stopniu niskim cechuje się poziomem wysokich zdolności i uzdolnień (15,8\%). Okazuje się, że w ocenie nauczycieli uczniowie pochodzenia robotniczego częściej niż pozostali wykazują przeciętny poziom wysokich uzdolnień $(70,6 \%)$. Z kolei blisko co czwarty uczeń $z$ rodziny inteligenckiej jest według nich wysoko uzdolniony $(22,8 \%)(p<0,05)$. Nauczyciele podkreślali, że uczniowie mieszkający na wsi częściej od ich rówieśników będących mieszkańcami miasta mają jedynie przeciętny poziom zdolności i uzdolnień $(87,5 \%)(\mathrm{p}<0,05)$.

Analizując strukturę wysokich uzdolnień, należy zauważyć, że badane osoby mają największe uzdolnienia w obszarze poznawczym $(1,58)$ i emocjonalnym $(1,20)$, natomiast mniejsze w obszarze społecznym $(0,88)$ i motywacyjno-wolicjonalnym $(0,79)$ (rysunek 2). 


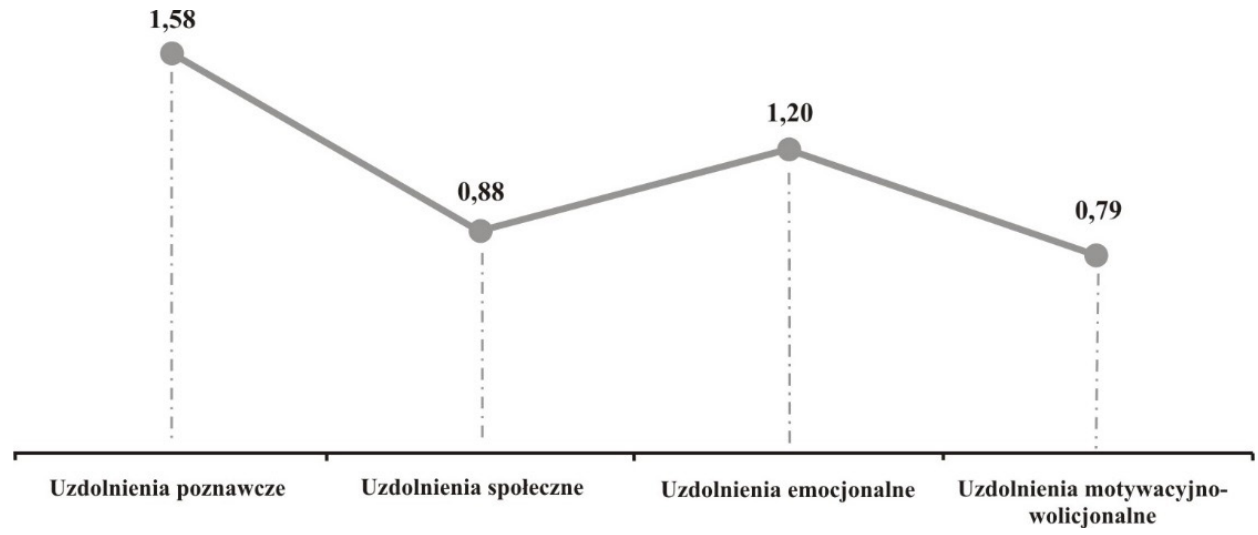

Rysunek 2. Struktura wysokich zdolności i uzdolnień uczniów w ocenie nauczycieli Źródło: opracowanie własne.

Tym samym spośród wielu procesów i cech nauczyciele, określając strukturę wysokich zdolności i uzdolnień, wybrali najwięcej funkcji związanych z czynnikami poznawczymi (10 elementów). Należy sądzić, że wynika to z ich doświadczenia związanego z nauczaniem, w toku którego zdolności i uzdolnienia się przejawiają najpełniej i są najlepiej obserwowalne.

Poziom wysokich uzdolnień poznawczych obliczono metodą odchyleń standardowych. Poziom przeciętny jest następujący: średnia $\mathrm{M}=14,85$, plus/minus jedno odchylenie standardowe $\mathrm{SD}=8,95$, mediana 15 , minimum 0 , maksimum 30. Poziom wysoki: średnia plus powyżej jedno i więcej odchyleń standardowych. Poziom niski: średnia minus poniżej jednego i więcej odchyleń standardowych. Niski poziom wysokich uzdolnień poznawczych wynosi poniżej 6 pkt, poziom średni - 6-23 pkt, a poziom wysoki - powyżej 23 pkt (tabela 6).

Tabela 6. Poziom wysokich uzdolnień poznawczych uczniów w ocenie badanych nauczycieli

\begin{tabular}{|c|c|c|}
\hline Wynik & Częstość & Procent \\
\hline Poziom niski (poniżej 6 pkt) & 35 & 15,8 \\
\hline Poziom przeciętny (6-23 pkt) & 135 & 61,1 \\
\hline Poziom wysoki (powyżej 23 pkt) & 51 & 23,1 \\
\hline Ogółem & 221 & 100,0 \\
\hline
\end{tabular}

Źródło: opracowanie własne.

Wyniki badań pozwalają stwierdzić, że dominuje przeciętny poziom wysokich uzdolnień poznawczych $(61,1 \%)$, przy czym uczniowie mieszkający na wsi częściej niż ich rówieśnicy z miasta mają przeciętny poziom uzdolnień poznawczych $(87,5 \%)(p<0,05)$. Jak ustalono, nauczyciele mężczyźni częściej niż kobiety 
diagnozowali wśród uczniów przeciętny poziom wysokich uzdolnień poznawczych $(71,7 \%)(p<0,05)$. Podobnie nauczyciele przedmiotów humanistycznych częściej niż nauczyciele przedmiotów matematyczno-przyrodniczych diagnozowali u uczniów przeciętny poziom wysokich uzdolnień poznawczych $(64,4 \%)(\mathrm{p}<0,05)$. Także nauczyciele z najniższym stażem zawodowym (do 5 lat) (70\%), pracujący na wsi $(71,1 \%)$, częściej niż inni wskazywali u uczniów przeciętny poziom wysokich uzdolnień poznawczych $(\mathrm{p}<0,05)$. Niemal co czwarty uczeń w ocenie pedagogów $(23,1 \%)$ wyróżnia się wysokim poziomem inteligencji, łatwością koncentracji i bardzo dobrą pamięcią, a przy tym jest niezwykle dociekliwy i szybko się uczy w porównaniu do swoich rówieśników. Jak stwierdzili nauczyciele, nie posiada tych walorów co szósty uczeń $(15,8 \%)$.

Według pedagogów wśród badanych uczniów w większości nie występuje poszukiwanie dodatkowej wiedzy (57,5\%), szybkość działania (54,3\%), bogaty zasób słownictwa $(54,8 \%)$, wysoka inteligencja $(51,1 \%)$. Natomiast wysoki poziom uzdolnień dotyczy takich funkcji, jak: logiczne myślenie (49,8\%), czytanie ze zrozumieniem (49,8\%), abstrakcyjne myślenie (48,4\%), szybkie zapamiętywanie (44,3\%).

Oceniono również poziom uzdolnień społecznych. Nauczyciele wybrali tylko pięć funkcji. Poziom wysokich uzdolnień społecznych obliczono metodą odchyleń standardowych. Poziom przeciętny jest następujący: średnia $\mathrm{M}=4,38$, plus/minus jedno odchylenie standardowe $\mathrm{SD}=2,77$, mediana 5 , minimum 0 , maksimum 15 . Poziom wysoki: średnia plus powyżej jedno i więcej odchyleń standardowych. Poziom niski: średnia minus poniżej jednego i więcej odchyleń standardowych. Niski poziom wysokich uzdolnień społecznych wynosi poniżej $2 \mathrm{pkt}$, poziom średni 2-7 pkt, a poziom wysoki - powyżej 7 pkt (tabela 7).

Tabela 7. Poziom wysokich uzdolnień społecznych uczniów w ocenie badanych nauczycieli

\begin{tabular}{|c|c|c|}
\hline Wynik & Częstość & Procent \\
\hline Poziom niski (poniżej 2 pkt) & 28 & 12,7 \\
\hline Poziom przeciętny (2-7 pkt) & 182 & 77,8 \\
\hline Poziom wysoki (powyżej 7 pkt) & 21 & 9,5 \\
\hline Ogółem & 221 & 100,0 \\
\hline
\end{tabular}

Źródło: opracowanie własne.

Należy zauważyć, że ponad trzy czwarte uczniów w ocenie nauczycieli (77,8\%) charakteryzuje się jedynie przeciętnym poziomem uzdolnień społecznych. Okazuje się, że uczniowie z dużych miast (powyżej 100 tys. mieszkańców) częściej niż inni cechują się przeciętnym poziomem wysokich uzdolnień społecznych $(81,3 \%)$ $(\mathrm{p}<0,05)$. Również uczniowie pochodzenia robotniczego najczęściej w ocenie pedagogów wykazują przeciętny poziom wysokich uzdolnień społecznych $(82,4 \%)$ $(\mathrm{p}<0,005)$. Należy odnotować, że wśród nauczycieli częściej kobiety niż mężczyź- 
ni diagnozowały u uczniów przeciętny poziom wysokich uzdolnień społecznych $(80,6 \%)(\mathrm{p}<0,05)$. Podobnie ocenili poziom wysokich uzdolnień społecznych nauczyciele przedmiotów humanistycznych w porównaniu do nauczycieli przedmiotów matematyczno-przyrodniczych $(64,4 \%)(\mathrm{p}<0,05)$. Jak ustalono, jedynie co dziesiąty badany $(9,5 \%)$ odznacza się adekwatnym zachowaniem społecznym. Co ósmy uczeń $(12,7 \%)$ wykazuje w tym zakresie duży deficyt.

Jak zauważyli nauczyciele, wśród badanych uczniów w zdecydowanej większości nie występuje brak samodzielności $(86,0 \%)$, uspołecznienia $(83,5 \%)$ czy złe funkcjonowanie w grupie $(85,5 \%)$. Co drugi uczeń jednak nie jest pewny siebie $(50,7 \%)$. Zdaniem nauczycieli uczniowie przejawiają wysoki poziom kultury osobistej $(60,6 \%)$.

Kolejnym analizowanym obszarem są wysokie uzdolnienia emocjonalne. Spośród analizowanych czynników pedagodzy wybrali do oceny cztery funkcje. Poziom wysokich uzdolnień emocjonalnych obliczono metodą odchyleń standardowych. Poziom przeciętny jest następujący: średnia $M=4,79$, plus/minus jedno odchylenie standardowe $\mathrm{SD}=3,43$, mediana 5, minimum 0, maksimum 12. Poziom wysoki: średnia plus powyżej jedno i więcej odchyleń standardowych. Poziom niski: średnia minus poniżej jednego i więcej odchyleń standardowych. Niski poziom uzdolnień emocjonalnych nie występuje, ponieważ średnia minus odchylenie standardowe daje wynik bliski zeru, poziom przeciętny wynosi do $8 \mathrm{pkt}$, a poziom wysoki - powyżej 8 pkt (tabela 8).

Tabela 8. Poziom wysokich uzdolnień emocjonalnych uczniów w ocenie badanych nauczycieli

\begin{tabular}{|c|c|c|}
\hline Wynik & Częstość & Procent \\
\hline Poziom niski nie występuje & 43 & 19,6 \\
\hline Poziom przeciętny (do 8 pkt) & 127 & 57,5 \\
\hline Poziom wysoki (powyżej 8 pkt) & 51 & 23,1 \\
\hline Ogółem & 221 & 100,0 \\
\hline
\end{tabular}

Źródło: opracowanie własne.

Jak wynika z uzyskanych danych, wśród badanych uczniów w ocenie ich nauczycieli częściej niż co drugi $(57,5 \%)$ charakteryzuje się poziomem przeciętnym wysokich uzdolnień emocjonalnych. Nauczyciele wskazali, że przeciętny poziom wysokich uzdolnień emocjonalnych najczęściej wykazują uczniowie mieszkający na wsi $(87,5 \%)(p<0,05)$. Częściej poziom ten diagnozowali nauczyciele przedmiotów humanistycznych niż nauczyciele przedmiotów matematyczno-przyrodniczych $(58,5 \%)$ oraz częściej kobiety niż mężczyźni $(58,3 \%)(\mathrm{p}<0,05)$. Ustalono także, że wysoki poziom wysokich uzdolnień w zakresie zrównoważenia emocjonalnego wyróżnia blisko co czwartego ucznia $(23,1 \%)$. W ocenie pedagogów nie występuje niski poziom wysokich uzdolnień emocjonalnych uczniów $(19,6 \%)$. 
Szczegółowa analiza danych empirycznych wykazała, że u badanych uczniów W większości nie zdiagnozowano zawziętości (84,6\%) i otwartości (54,8\%). Ankietowani nie są również optymistyczni $(46,6 \%)$. Tylko co drugi uczeń charakteryzuje się wysokim poziomem koleżeńskości $(51,1 \%)$.

Ostatnim analizowanym czynnikiem na poziomie wysokich uzdolnień są funkcje motywacyjno-wolicjonalne. Nauczyciele wybrali cztery elementy. Poziom wysokich uzdolnień motywacyjno-wolicjonalnych obliczono metodą odchyleń standardowych. Poziom przeciętny jest następujący: średnia $\mathrm{M}=3,15$, plus/minus jedno odchylenie standardowe $\mathrm{SD}=3,31$, mediana 3, minimum 0 , maksimum 12 . Poziom wysoki: średnia plus powyżej jedno i więcej odchyleń standardowych. Poziom niski: średnia minus poniżej jednego i więcej odchyleń standardowych. Niski poziom wysokich uzdolnień motywacyjno-wolicjonalnych nie występuje, ponieważ średnia minus odchylenie standardowe daje wynik ujemny, poziom średni do 6 pkt, a poziom wysoki - powyżej 6 pkt (tabela 9).

Tabela 9. Poziom wysokich uzdolnień motywacyjno-wolicjonalnych uczniów w ocenie badanych nauczycieli

\begin{tabular}{|c|c|c|}
\hline Wynik & Częstość & Procent \\
\hline Poziom niski nie występuje & 85 & 38,5 \\
\hline Poziom przeciętny (do 6 pkt) & 106 & 48,0 \\
\hline Poziom wysoki (powyżej 6 pkt) & 30 & 13,6 \\
\hline Ogółem & 221 & 100,0 \\
\hline
\end{tabular}

Źródło: opracowanie własne.

W przypadku badanej próby u 38,5\% osób niski poziom wysokich uzdolnień motywacyjno-wolicjonalnych nie występuje. Natomiast co drugi badany $(48,0 \%)$ przejawia przeciętny poziom wysokich uzdolnień motywacyjno-wolicjonalnych. Najczęściej są to uczniowie pochodzenia chłopskiego $(51,4 \%)(\mathrm{p}<0,05)$. Wśród badanych nauczycieli częściej kobiety niż mężczyźni diagnozowały u uczniów przeciętny poziom wysokich uzdolnień motywacyjno-wolicjonalnych $(49,1 \%)$ oraz częściej nauczyciele przedmiotów humanistycznych niż nauczyciele przedmiotów matematyczno-przyrodniczych $(50,8 \%)(p<0,05)$. Jedynie co siódmy uczeń $(13,6 \%)$ w ocenie pedagogów wyróżnia się wysokim poziomem ambicji, aktywności, inicjatywy i skłonności do ponoszenia ryzyka.

Na podstawie danych empirycznych można stwierdzić, że zdecydowana większość badanych uczniów nie pracuje automatycznie $(81,0 \%)$, nie przejawia wzmożonej aktywności $(74,7 \%)$, nie ma szczególnych zainteresowań $(71,0 \%)$ i wysokiej motywacji $(56,6 \%)$. Tylko co trzecia osoba jest wysoko zmotywowana $(34,6 \%)$, a co piąta ma szczególne zainteresowania $(21,3 \%)$. 
Poziom niskich zdolności i uzdolnień obliczono metodą odchyleń standardowych. Poziom przeciętny jest następujący: średnia $M=9,67$, plus/minus jedno odchylenie standardowe $\mathrm{SD}=10,28$, mediana 6 , minimum 0 , maksimum 50 . Poziom wysoki: średnia plus powyżej jedno i więcej odchyleń standardowych. Poziom niski: średnia minus poniżej jednego i więcej odchyleń standardowych. Niski poziom niskich zdolności i uzdolnień nie występuje, ponieważ średnia minus odchylenie standardowe daje wynik ujemny, poziom średni do $20 \mathrm{pkt}$, a poziom wysoki - powyżej 20 pkt (tabela 10).

Tabela 10. Poziom niskich zdolności i uzdolnień uczniów w ocenie badanych nauczycieli

\begin{tabular}{|c|c|c|}
\hline Wynik & Częstość & Procent \\
\hline Poziom niski nie występuje & 33 & 14,9 \\
\hline Poziom przeciętny (do 20 pkt) & 157 & 71,0 \\
\hline Poziom wysoki (powyżej 20 pkt) & 31 & 14,1 \\
\hline Ogółem & 221 & 100,0 \\
\hline
\end{tabular}

Źródło: opracowanie własne.

Zgodnie z uzyskanymi wynikami należy odnotować, że w badanej próbie u 14,9\% osób nie występuje niski poziom niskich zdolności i uzdolnień. Natomiast blisko trzy czwarte $(71,0 \%)$ uczniów w ocenie nauczycieli charakteryzuje się przeciętnym poziomem niskich zdolności i uzdolnień. W tej grupie uczniów najczęściej znajdują się osoby pochodzenia inteligenckiego $(73,3 \%)$ oraz osoby mieszkające w małych miastach (do 50 tys. mieszkańców) $(76,1 \%)(\mathrm{p}<0,05)$. Z analiz wynika, że nauczyciele ze stażem zawodowym od 16 do 20 lat częściej niż pozostali diagnozowali u uczniów przeciętny poziom niskich uzdolnien $(81,2 \%)$, podobnie jak nauczyciele przedmiotów matematyczno-przyrodniczych $(71,8 \%)$ oraz nauczyciele pracujący na wsi $(82,5 \%)(\mathrm{p}<0,05)$. Z kolei wysoki poziom niskich zdolności i uzdolnień zdaniem nauczycieli dotyczy co siódmego ucznia $(14,1 \%)$.

Dokonując analizy struktury zmiennych opisujących niskie zdolności i uzdolnienia, należy zauważyć, że u badanych uczniów najniższe są uzdolnienia charakterologiczne $(0,38)$ i poznawcze $(0,47)$. W małym stopniu są oni systematyczni, pracowici, rzetelni i wytrwali w dążeniu do celu oraz nie posiadają łatwości koncentracji i mają problem z zapamiętywaniem, są też mało dociekliwi. Najwyższe są zaś motywacyjno-wolicjonalne $(0,70)$ i emocjonalne $(0,58)$ zdolności i uzdolnienia. Może to świadczyć o tym, że uczniowie wykazują się ambicją, aktywnością i inicjatywą oraz są śmiali i odważni, a także zrównoważeni emocjonalnie (rysunek 3 ). 


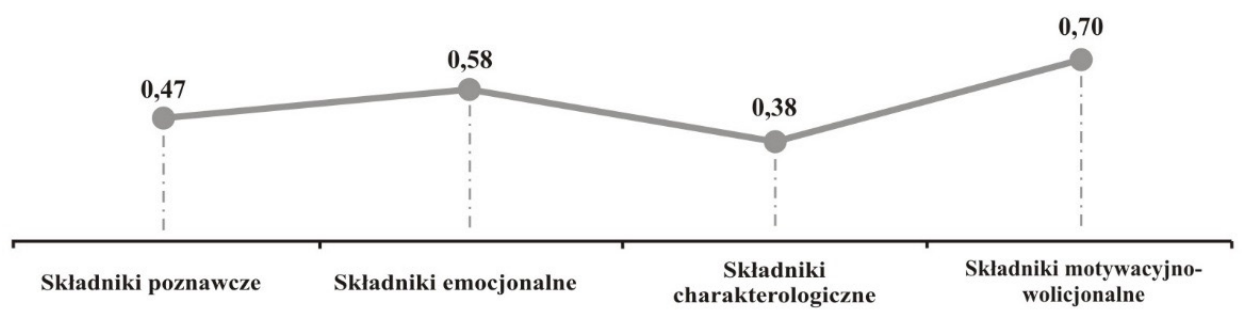

Rysunek 3. Struktura niskich zdolności i uzdolnień uczniów w ocenie badanych nauczycieli Źródło: opracowanie własne.

Spośród wielu procesów i cech świadczących o niskich uzdolnieniach uczniów badani nauczyciele wybrali najwięcej funkcji związanych z czynnikami poznawczymi - było to aż dziewięć elementów. Poziom niskich uzdolnień poznawczych obliczono metodą odchyleń standardowych. Poziom przeciętny jest następujący: średnia $\mathrm{M}=4,21$, plus/minus jedno odchylenie standardowe $\mathrm{SD}=5,65$, mediana 2, minimum 0, maksimum 25. Poziom wysoki: średnia plus powyżej jedno i więcej odchyleń standardowych. Poziom niski: średnia minus poniżej jednego i więcej odchyleń standardowych. Niski poziom niskich uzdolnień poznawczych nie występuje, ponieważ średnia minus odchylenie standardowe daje wynik ujemny, poziom średni do 9 pkt, a poziom wysoki - powyżej 9 pkt (tabela 11). W przypadku badanej próby u 44,8\% osób nie występuje niski poziom niskich uzdolnień poznawczych. Przeciętny poziom niskich uzdolnień jest udziałem blisko czterech na dziesięciu uczniów (38,5\%). Poziom wysoki niskich uzdolnień poznawczych uczniów w ocenie nauczycieli charakteryzuje co szóstego ucznia $(16,7 \%)$.

Tabela 11. Poziom niskich uzdolnień poznawczych uczniów w ocenie badanych nauczycieli

\begin{tabular}{|c|c|c|}
\hline Wynik & Częstość & Procent \\
\hline Poziom niski nie występuje & 99 & 44,8 \\
\hline Poziom przeciętny (do 9 pkt) & 85 & 38,5 \\
\hline Poziom wysoki (powyżej 9 pkt) & 37 & 16,7 \\
\hline Ogółem & 221 & 100,0 \\
\hline
\end{tabular}

Źródło: opracowanie własne.

Na podstawie danych empirycznych można stwierdzić, że zdecydowana większość uczniów nie wykazuje braku wzorców (90,0\%), nie ma słabej pamięci $(86,9 \%)$, nie popełnia licznych błędów $(81,9 \%)$, nie ma problemów w czytaniu ze zrozumieniem $(86,0 \%)$, nie ma ubogiego słownictwa $(78,7 \%)$, nie przejawia zaburzonego toku myślenia przyczynowo-skutkowego $(77,8 \%)$, nie ma też trudności w skojarzeniach $(76,9 \%)$, braków w umiejętności wnioskowania $(76,5 \%)$ oraz problemów z koncentracją (72,9\%). Problemy na wysokim poziomie z koncentracją 
uwagi ma jedynie co szósta osoba $(15,8 \%)$, a co dziewiąta popełnia liczne błędy $(11,8 \%)$ i wykazuje zaburzony tok myślenia przyczynowo-skutkowego $(10,9 \%)$ oraz ma problemy z wnioskowaniem $(10,4 \%)$ i trudności w skojarzeniach $(10,0 \%)$.

Kolejny element prowadzonych analiz to określenie poziomu uzdolnień emocjonalnych uczniów w ocenie nauczycieli. Poziom niskich uzdolnień emocjonalnych obliczono metodą odchyleń standardowych. Poziom przeciętny jest następujący: średnia $\mathrm{M}=2,92$, plus/minus jedno odchylenie standardowe $\mathrm{SD}=3,12$, mediana 3,00, minimum 0, maksimum 13. Poziom wysoki: średnia plus powyżej jedno i więcej odchyleń standardowych. Poziom niski: średnia minus poniżej jednego i więcej odchyleń standardowych. Niski poziom niskich uzdolnień emocjonalnych nie występuje, ponieważ średnia minus odchylenie standardowe daje wynik ujemny, poziom średni do 6 pkt, a poziom wysoki - powyżej 6 pkt (tabela 12).

Tabela 12. Poziom niskich uzdolnień emocjonalnych uczniów w ocenie badanych nauczycieli

\begin{tabular}{|c|c|c|}
\hline Wynik & Częstość & Procent \\
\hline Poziom niski nie występuje & 88 & 39,8 \\
\hline Poziom przeciętny (do 6 pkt) & 107 & 48,4 \\
\hline Poziom wysoki (powyżej 6 pkt) & 26 & 11,8 \\
\hline Ogółem & 221 & 100,0 \\
\hline
\end{tabular}

Źródło: opracowanie własne.

Z uzyskanych danych wynika, że w przypadku badanej próby u 39,8\% osób nie występuje niski poziom niskich uzdolnień emocjonalnych. Poziom przeciętny w zakresie niskich uzdolnień dotyczy co drugiego ucznia (48,4\%), a poziom wysoki odnosi się do co ósmej osoby $(11,8 \%)$.

Na podstawie szczegółowej analizy wyników badań empirycznych należy stwierdzić, że zdecydowana większość uczniów nie jest depresyjna (91,9\%) oraz nie ma zahamowań (77,4\%). U większości nie występuje nieśmiałość $(77,4 \%)$, brak odwagi (71,5\%) czy niepewność $(68,8 \%)$.

Analizując dane dotyczące niskich uzdolnień charakterologicznych, stwierdzono, że średni poziom niskich uzdolnień charakterologicznych wynosi 1,15, odchylenie standardowe 2,04, mediana 0 , minimum 0 , maksimum 9. Poziom niskich uzdolnień charakterologicznych obliczono metodą odchyleń standardowych. Poziom przeciętny jest następujący: średnia $\mathrm{M}=1,15$, plus/minus jedno odchylenie standardowe $\mathrm{SD}=2,04$. Poziom wysoki: średnia plus powyżej jedno i więcej odchyleń standardowych. Poziom niski: średnia minus poniżej jednego i więcej odchyleń standardowych. Niski poziom niskich uzdolnień charakterologicznych nie występuje, ponieważ średnia minus odchylenie standardowe daje wynik ujemny, poziom średni do 3 pkt, a poziom wysoki - powyżej 3 pkt (tabela 13). 
Tabela 13. Poziom niskich uzdolnień charakterologicznych uczniów w ocenie badanych nauczycieli

\begin{tabular}{|c|c|c|}
\hline Wynik & Częstość & Procent \\
\hline Poziom niski nie występuje & 152 & 68,8 \\
\hline Poziom przeciętny (do 3 pkt) & 49 & 22,2 \\
\hline Poziom wysoki (powyżej 3 pkt) & 20 & 9,0 \\
\hline Ogółem & 221 & 100,0 \\
\hline
\end{tabular}

Źródło: opracowanie własne.

Należy podkreślić, że w przypadku badanej próby u dwóch trzecich uczniów $(68,8 \%)$ nie występuje niski poziom niskich uzdolnień charakterologicznych. Częściej niż u co czwartego ucznia nauczyciele $(22,2 \%)$ stwierdzili poziom przeciętny w zakresie niskich uzdolnień charakterologicznych. Co jedenasty uczeń $(9,0 \%)$ ich zdaniem wykazuje wysoki poziom w zakresie niskich uzdolnien charakterologicznych.

Ze szczegółowej analizy uzyskanego materiału empirycznego wynika, że w wylosowanej próbie uczniów prawie nie ma osób bezradnych $(92,3 \%)$, poza tym zdecydowana większość ma własne zdanie $(86,4 \%)$ oraz nie zniechęca się zbyt szybko $(75,6 \%)$.

Ostatnim elementem prowadzonych analiz w zakresie zdolności i uzdolnień uczniów jest określenie poziomu ich niskich uzdolnień motywacyjno-wolicjonalnych. Poziom ten obliczono metodą odchyleń standardowych. Poziom przeciętny jest następujący: średnia $\mathrm{M}=1,4$, plus/minus jedno odchylenie standardowe $\mathrm{SD}=$ 1,93 , mediana 0,00 , minimum 0 , maksimum 6 . Poziom wysoki: średnia plus powyżej jedno i więcej odchyleń standardowych. Poziom niski: średnia minus poniżej jednego i więcej odchyleń standardowych. Ustalono, że niski poziom uzdolnień motywacyjno-wolicjonalnych u uczniów nie występuje, ponieważ średnia minus odchylenie standardowe daje wynik ujemny, poziom średni do $3 \mathrm{pkt}$, a poziom wysoki - powyżej 3 pkt (tabela 14).

Tabela 14. Poziom niskich uzdolnień motywacyjno-wolicjonalnych uczniów w ocenie badanych nauczycieli

\begin{tabular}{|c|c|c|}
\hline Wynik & Częstość & Procent \\
\hline Poziom niski nie występuje & 133 & 60,2 \\
\hline Poziom przeciętny (do 3 pkt) & 63 & 28,5 \\
\hline Poziom wysoki (powyżej 3 pkt) & 25 & 11,3 \\
\hline Ogółem & 221 & 100,0 \\
\hline
\end{tabular}

Źródło: opracowanie własne.

Na podstawie uzyskanych danych można skonstatować, że w przypadku badanej próby u $60,2 \%$ uczniów nie występuje w ocenie badanych nauczycieli niski 
poziom niskich uzdolnień motywacyjno-wolicjonalnych. Trzech na dziesięciu uczniów $(28,5 \%)$ wykazuje przeciętny poziom niskich uzdolnień motywacyjno-wolicjonalnych. Wysoki poziom w tym zakresie charakteryzuje co dziewiątego ucznia $(11,3 \%)$.

Ze szczegółowej analizy wynika, że zdecydowana większość uczniów w ocenie badanych nauczycieli nie ma słabej motywacji do nauki $(86,4 \%)$ oraz nie brakuje im systematyczności w pracy $(62,4 \%)$ (tabela 15$)$.

Tabela 15. Określenia opisujące niskie uzdolnienia motywacyjno-wolicjonalne uczniów w ocenie badanych nauczycieli (dane w \%)

\begin{tabular}{|c|c|c|c|c|c|}
\hline \multirow[b]{2}{*}{ Lp. } & \multirow{2}{*}{$\begin{array}{c}\text { Nazwa funkcji (proce- } \\
\text { su, cechy) }\end{array}$} & \multicolumn{4}{|c|}{ Ranga } \\
\hline & & $\begin{array}{c}\text { nie } \\
\text { występuje }\end{array}$ & $\begin{array}{c}\text { poziom } \\
\text { niski }\end{array}$ & $\begin{array}{c}\text { poziom } \\
\text { średni }\end{array}$ & $\begin{array}{l}\text { poziom } \\
\text { wysoki }\end{array}$ \\
\hline MWN26 & Brak systematyczności & 62,4 & 0,9 & 8,6 & 28,1 \\
\hline MWN37 & Słaba motywacja & 86,4 & - & 3,2 & 10,4 \\
\hline
\end{tabular}

Źródło: opracowanie własne.

\section{ZAKOŃCZENIE}

Analizując dane przytoczone w niniejszym artykule, należy stwierdzić, że badani nauczyciele różnicują zdolności i uzdolnienia uczniów za pomocą ocen szkolnych (Borzym, 1979; Dobrołowicz, 1995; Gruszczyk-Kolczyńska, 2012). Z kolei analizując wyniki SdBZiUU (eksperymentalne narzędzie badawcze), należy skonstatować, że opisując swoich uczniów, nauczyciele użyli mniej niż połowę dostępnych w skali określeń - 44 ze 100 analizowanych, co może wskazywać na ograniczoną znajomość cech charakterystycznych dla każdego ucznia, które są ważnymi wskaźnikami w rozpoznawaniu zdolności. Ponad połowa uczestniczących w badaniach nauczycieli wskazała, że rozpoznają zdolności i uzdolnienia u wskazanych uczniów, jednak co szósty nauczyciel stwierdził ich całkowity brak u swoich podopiecznych.

Środowisko rodzinne i lokalne według omawianych tu badań w istotnym stopniu różnicuje ogólny poziom zdolności i uzdolnień uczniów, nauczyciele bowiem częściej dostrzegają zdolności i uzdolnienia u uczniów pochodzenia chłopskiego. Nauczyciele pracujący na wsi częściej diagnozują zdolności i uzdolnienia u swoich uczniów.

Stwierdzono brak istotnych różnic w diagnozowaniu uczniów przez nauczycieli z bloków przedmiotów humanistycznych i matematyczno-przyrodniczych. Analizując opisy uczniów wykazujących według badanych nauczycieli poziom wysokich zdolności i uzdolnień, nauczyciele wybrali najwięcej cech związanych ze zdolnościami poznawczymi uczniów. Co ciekawe, są one najłatwiej rozpozna- 
walne. Należą do nich: szybkie zapamiętywanie, dokładność i logiczne myślenie. Znacznie mniej określeń dotyczyło opisu czynników społecznych. Większość badanych nauczycieli wykazała przeciętny poziom ich występowania. Zwracali oni uwagę przede wszystkim na kulturę osobistą uczniów.

Przy czynnikach emocjonalnych badani nauczyciele dostrzegli tylko kilka funkcji. Większość wskazała na przeciętne występowanie cech emocjonalnych u swoich uczniów. Najmniej określeń dotyczyło cech motywacyjno-wolincjonalnych. Analizując opisy uczniów wykazujących według nauczycieli poziom niskich zdolności i uzdolnień, nauczyciele - tak jak w przypadku uzdolnień wysokich wybrali najwięcej cech związanych z cechami poznawczymi, a następnie kilka cech związanych z pozostałymi czynnikami.

Podsumowując powyższe analizy, należy stwierdzić, że ocena i rozróżnienie uczniów na zdolnych lub niezdolnych odbywa się nadal za pomocą czynników poznawczych, czyli poziomu inteligencji danej jednostki. Nauczyciele są zakłopotani i niechętni do analizy swoich uczniów pod względem innych czynników, gdyż nie znają swoich uczniów zbyt dobrze.

\section{BIBLIOGRAFIA}

Bandura, A. (1974). Social Learning Theory. Englewood Cliffs: Prentice Hall.

Borzym, I. (1979). Uczniowie zdolni. Warszawa: PWN.

Butler-Por, N. (1993). Underachieving gifted students. W: K.A. Heller, F.J. Mönks, A.H. Passow (eds.), International Handbook of Research and Development of Giftedness and Talent (s. 649-668). Oxford: Pergamon Press.

Dobrołowicz, W. (1995). Psychodydaktyka kreatywności. Warszawa: WSPS.

Dyrda, B. (2007). Zjawiska niepowodzeń szkolnych uczniów zdolnych. Rozpoznawanie i przeciwdziałanie. Kraków: Oficyna Wydawnicza Impuls.

Dyrda, B. (2012). Edukacyjne wspomaganie rozwoju uczniów zdolnych - studium społeczno-pedagogiczne. Warszawa: Wydawnictwo Akdemickie „Żak”.

Ekiert-Grabowska, D. (1994). Dzieci nieakceptowane w klasie szkolnej. Warszawa: WSiP.

Galton, F. (1869). Dziedziczny geniusz. Badanie jego praw i konsekwencji. Londyn: Macmillan \& Co.

Giza, T. (2006). Socjopedagogiczne uwarunkowania procesów identyfikowania oraz rozwoju zdolności uczniów w szkole. Kielce: Wydawnictwo Akademii Świętokrzyskiej.

Gondzik, E. (1978). Kariery szkolne uczniów zdolnych. Warszawa: WSiP.

Gruszczyk-Kolczyńska, E. (2012). Argumenty przemawiające za wczesnym rozpoznawaniem uzdolnień u dzieci. W: E. Gruszczyk-Kolczyńska (red.), O dzieciach matematycznie uzdolnionych (s. 31-36). Warszawa: Wydawnictwo Nowa Era.

Grzywak-Kaczyńska, M. (1935). Testy w szkole. Warszawa: Nasza Księgarnia.

Hoffman, J.L., Wasson, F.R., Christianson, B.P. (1985). Personal development for the gifted underachiever. Gifted Child Today, 8(3), 12-14. DOI: https://doi.org/10.1177/107621758500800305

Hornowski, B. (1985). Psychologia różnic indywidualnych. Warszawa: WSiP.

Kingore, B. (2004). Differentiation: Simplified, Realistic, and Effective. Austin: Professional Associates Publishing.

Kwieciński, Z. (1980). Drogi szkolne młodzieży a środowisko. Warszawa: WSiP.

Lewowicki, T. (1986). Kształcenie uczniów zdolnych. Warszawa: WSiP. 
Limont, W. (2005). Uczeń zdolny. Gdańsk: GWP.

Limont, W. (2010). Uczeń zdolny - jak go rozpoznawać i jak z nim pracować. Gdańsk: GWP.

Limont, W., Cieślikowska, J., Dreszer, J. (red.). (2008). Zdolności, talent, twórczość (T. 1-2). Torun: Wydawnictwo Uniwersytetu Mikołaja Kopernika.

Magda-Adamowicz, M. (red.). (2011). Twórczy pedagogicznie nauczyciele klas młodszych. Obszary i panorama problematyki. Gniezno: Gnieźnieńska Wyższa Szkoła Humanistyczno-Menedżerska Milenium.

Magda-Adamowicz, M. (red.). (2015). Twórczy nauczyciele i twórczy uczniowie. W: I. Nowosad, I. Mortag, J. Ondráková (red.), Jakość życia i jakość szkoły. Wprowadzenie w zagadnienia jakości i efektywności pracy szkoły (s. 286-303). Zielona Góra: Oficyna Wydawnicza Uniwersytetu Zielonogórskiego.

Popek, S. (1987). Z badań nad zdolnościami i uzdolnieniami specjalnymi młodzieży. Lublin: Wydawnictwo UMCS.

Popek, S. (1996). Zdolności i uzdolnienia jako osobowościowe właściwości człowieka. Lublin: Wydawnictwo UMCS.

Popek, S. (2015). W kręgu aktywności twórczej. Lublin: Wydawnictwo UMCS.

Renzulli, J.S., Reid, B.D., Gubbins, E.J. (1992). Setting an Agenda: Research Priorities for the Gifted and Talented Through the Year 2000. Storrs: University of Connecticut, The National Research Center on the Gifted and Talented.

Schwitzgebel, E. (1965). The Unreliability of Naive Introspection. The Philosophical Review, 117(2), 245-273. DOI: https://doi.org/10.1215/00318108-2007-037

Sękowski, A.E. (2001). Osiagnięcia szkolne ucziów zdolnych. Lublin: Wydawnictwo KUL.

Szabos, J. (1989). Bright child, gifted learner. Challenge, 34.

Szmidt, K.J. (2007). Pedagogika twórczości. Gdańsk: GWP.

Tyszkowa, M. (1990). Zdolności, osobowość i działalność uczniów. Warszawa: PWN.

\section{ABSTRACT}

Educating gifted students is a specific challenge for modern schools, it requires an appropriate educational policy and financial outlays for education. However, the necessary and most important factor are properly prepared teachers who are able to recognize the educational and upbringing needs of their students. It is extremely important that teachers accurately diagnose students' abilities and talents so that they can develop them and create optimal conditions for their development. Currently, the most common form used by teachers is the division into gifted and non-gifted students using school grades. This method seems to be inadequate. Therefore, an attempt has been made to create a research tool - Scale for the Study of Abilities and Giftedness by Stanisław Popek and Kamila M. Kosiak intended for teachers to recognize abilities and giftedness on the basis of theoretical foundations and standardized concepts of abilities and giftedness. The results of the conducted research confirm the correctness of the adopted solutions.

Keywords: teacher; gifted student; pedagogical diagnosis 